The mechanisms by which HLA-B27 increase susceptibility to inflammatory arthritis are not yet clear. Many bacteria bear cell-surface antigens closely related to mammalian tissue antigens, and in mice these cross-reactive antigens may be responsible for the pathogenicity of Salmonella typhimurium. ${ }^{40}$ Preliminary evidence also suggests cross-reactivity between certain Gram-negative bacterial antigens and HLA-B27, ${ }^{41}$ which could lead to autoimmunity. If there is similar crossreactivity between $C$ trachomatis and human tissues this could also provide a basis for autoimmune processes, which may play an important part in the pathogenesis of reactive arthritis.

As all our patients took antibiotics as soon as non-specific urethritis was diagnosed, the risk of arthritis is clearly not eliminated by the standard antibiotic treatment we used. Others $^{42}$ have concluded that the course of such arthritis is not influenced by antibiotics; but a controlled trial would be needed to show whether they can prevent it or modify its course.

The importance of our study lies in the clear demonstration of interaction between genetic and environmental factors in an inflammatory rheumatic disease. In spite of our failure to implicate a specific organism as the sole cause of SARA, further studies on such patients with appropriate methods should help to identify the mechanisms whereby a susceptible host responds abnormally to his environment.

We are indebted to Dr J L Fluker, consultant physician, for permission to study his patients and to the medical and nursing staff of the genitourinary medicine department, West London Hospital, for their help with this work. We are also grateful to Dr J D Oriel, consultant physician, department of genitourinary medicine, University College Hospital, for the microbiological studies and for helpful discussion, and to Miss Jean Owen and Miss Veronique Lam Po Tang, who carried out the culture of chlamydia. This work was supported by a grant from the Arthritis and Rheumatism Council and Abbott Laboratories.

\section{References}

${ }^{1}$ Brodie, B C, Pathological and Surgical Observations on Disease of The foints. London, Longman, 1818.

2 Fiessinger, N, and Leroy, E, Bulletins et Mémoires de la Société de Medecale de Hopitaux de Paris, 1916, 40, 2030.

${ }^{3}$ Reiter, H, Deutsche Medizinische Wochenschrift, 1916, 42, 1535.

4 Paronen, I, Acta Medica Scandinavica, 1948, 212, suppl, p 1.

${ }^{5}$ Noer, H R, Fournal of the American Medical Association, 1966, 198, 693.
${ }^{6}$ Warren, C P W, Annals of the Rheumatic Diseases, 1970, 29, 483.

7 Ahvonen, P, Annals of Clinical Research, 1972, 4, 39.

${ }^{8}$ Aho, K, et al, Arthritis and Rheumatism, 1974, 17, 521.

${ }^{9}$ Gordon, F B, et al, Fournal of Infectious Diseases, 1969, 120, 451.

${ }_{10}$ Prentice, M J, Taylor-Robinson, D, and Csonka, G W, British fournal of Venereal Diseases, 1976, 52, 269.

${ }^{11}$ Richmond, S J, Hilton, A L, and Clarke, S K R, British fournal of Venereal Diseases, $1972,48,437$.

12 Oriel, J D, et al, British fournal of Venereal Diseases, 1976, 52, 46.

13 Alani, M D, et al, British Fournal of Venereal Diseases, 1977, 53, 88

${ }^{14}$ Holmes, K K, et al, New England Fournal of Medicine, 1975, 292, 1199.

${ }^{15}$ Schachter, J, et al, fournal of the American Medical Association, 1975, 231, 1252 .

${ }^{16}$ Darougar, S, Kinnison, J R, and Jones, B R, in International Congress Series No 223, ed R L Nichols, p 501. Amsterdam, Excerpta Medica, 1971.

${ }_{17}$ Smith, D E, et al, Arthritis and Rheumatism, 1973, 16, 21.

${ }^{18}$ Digiacomo, R F, et al, British fournal of Venereal Diseases, 1975, 51, 310.

${ }_{19}$ Dawson, C R, et al, Archives of Ophthalmology, 1970, 83, 300.

${ }^{20}$ Vaughan-Jackson, J D, et al, British fournal of Venereal Diseases, 1972 48,445 .

${ }^{21}$ Gordon, F B, et al, British fournal of Venereal Diseases, 1973, 49, 376.

${ }^{22}$ Schachter, $\mathrm{J}$, in Infection and Immunology in the Rheumatic Diseases, ed D C Dumonde. London, Blackwell, 1976.

23 Amor, B, et al, Revue de Rheumatisme et des Maladies Ostéo-articulaires, 1972, 39, 671 .

${ }^{24}$ Doury, P, Pattin, S, and Durosoir, J L, Revue de Rheumatisme et des Maladies Ostéo-articulaires, 1973, 40, 643.

${ }^{25}$ Darougar, S, in Sexually Transmitted Diseases, ed R D Catterall and C S Nicol. London, Academic Press, 1976.

${ }^{26}$ Brewerton, D A, et al, Lancet, 1973, 2, 996.

27 Woodrow, J C, Tissue Antigens, 1974, 4, 533.

${ }^{28}$ Morris, R, et al, New England fournal of Medicine, 1974, 290, 554.

${ }^{29}$ Friis, J, and Sveigaard, A, Lancet, 1974, 2, 1350.

${ }^{30}$ Hakansson, U, Low, B, and Eitrem, R, Tissue Antigens, 1975, 6, 366.

${ }^{31}$ Calin, A, and Fries, J F, Annals of the Rheumatic Diseases, 1976, 35, 287

32 Sairainen, E, and Tiilikainen, A, Scandinavian fournal of Rheumatology 1975, 8, Abs 30-11, suppl 1.

${ }^{33}$ Oriel, J D, et al, British fournal of Venereal Diseases, 1972, 48, 429.

${ }^{34}$ Dunlop, E M C, Vaughan-Jackson, J D, and Darougar, S, British fournal of Venereal Diseases, 1972, 48, 421.

${ }^{35}$ Reeve, P, Owen, J, and Oriel, J D, Fournal of Clinical Pathology, 1975, 28, 910 .

${ }^{36}$ Woolf, B, Annals of Human Genetics, 1955, 19, 125.

37 Festenstein, H, et al, Lancet, 1971, 2, 227.

${ }^{38}$ Calin, A, and Fries, J F, New England fournal of Medicine, 1975, 293, 835.

${ }^{39}$ Cohen, L M, et al, Annals of Internal Medicine, 1976, 84, 1.

${ }^{40}$ Rowley, D, and Jenkin, C R, Nature, 1962, 193, 151.

${ }^{41}$ Ebringer, A, et al, in $H L A$ and Disease, ed V Dausset and A Svejgaard, p 27. Paris, INSERM, 1976.

42 Popert, A J, Gill, A J, and Laird, S M, British fournal of Venereal Diseases, 1964, 40, 196.

(Accepted 8 December 1977)

\title{
Vitamin D status of Asian infants
}

\author{
NICOLA SINGLETON, S M TUCKER
}

British Medical fournal, 1978, 1, 607-610

\section{Summary and conclusions}

Vitamin $D$ intakes of infants aged 6 and 18 months from the Asian community in Southall, Middlesex, were studied to assess the effectiveness of food fortification as a means of preventing vitamin $D$ deficiency. Infants aged 6 months generally had similar diets to white children of

Department of Paediatrics, Hillingdon Hospital, Uxbridge, Middlesex UB8 3NN

NICOLA SINGLETON, MSC, research assistant (present address: Department of Public Health, Port Moresby, Papua, New Guinea)

S M TUCKER, FRCPED, DCH, consultant paediatrician the same age and had reasonable vitamin $D$ intakes owing to consumption of fortified dried milks and cereals, reinforced by health visitors and baby clinics. Children aged 18 months, however, ate largely Asian diets and had much lower vitamin $D$ intakes than the 6-month-old group with a corresponding increase in symptoms of vitamin $D$ deficiency.

Hence new measures for preventing vitamin $D$ deficiency should probably be aimed at children aged over 1 year. The results of this survey suggest that fortifying chapati flour would be the most effective method of doing this.

\section{Introduction}

Clinical and subclinical vitamin $\mathrm{D}$ deficiency in Asian immigrants has been widely reported. ${ }^{1-6}$ Although rickets and 
osteomalacia occur in the indigenous population and other immigrant groups, ${ }^{7-9}$ vitamin $D$ deficiency as a public health problem seems to be largely confined to Asians. " Widespread vitamin $\mathrm{D}$ deficiency among Asians is usually explained by their characteristic dietary and social habits. Several possible preventive measures have been proposed, including fortification of some foodstuff regularly consumed by Asians-for example, chapati flour, ghee, or milk ${ }^{112}$ - which would not necessitate a change in their dietary habits.

Surveys of the incidence of vitamin $D$ deficiency and the dietary habits of Asian immigrants have concentrated on adults and schoolchildren. ${ }^{3} 561314$ As rickets has also been reported in Asian children aged under 5 years $^{13}$ we undertook a study of the vitamin D status and dietary habits of infants aged 6 and 18

TABLE I-Proportion of infants in total sample being breast-fed at various ages

\begin{tabular}{r|c|c|c|c|c}
\hline Age: & $-\frac{2 \text { weeks }}{17(45)}$ & $\frac{2 \text { weeks }}{10(26)}$ & $\frac{2 \text { months }}{5(13)}$ & $\frac{3 \text { months }}{4(11)}$ & $\frac{>6 \text { months }}{2(5)}$ \\
\hline No $\left({ }^{\prime \prime}\right)$ of infants &
\end{tabular}

TABLE II-Ages at which children in the two groups received fortified dried milk. Figures are numbers $(\%)$ of children

\begin{tabular}{|c|c|c|c|c|c|}
\hline \multirow{2}{*}{ Group } & \multirow{2}{*}{ No } & \multicolumn{4}{|c|}{ Age (months) } \\
\hline & & 3 & 6 & 9 & 12 \\
\hline $\begin{array}{l}\text { 6-month age group } \\
18 \text {-month age group }\end{array}$ & $\begin{array}{l}18 \\
19^{*}\end{array}$ & $\begin{array}{r}100(18) \\
74(14)\end{array}$ & $\begin{array}{l}67(12) \\
42(8)\end{array}$ & $26(5)$ & 0 \\
\hline
\end{tabular}

*In one case the age at which dried milk was stopped was not known.

TABLE III-Proportion of children in total sample $(n=36)^{*}$ receiving solids at different ages

\begin{tabular}{|c|c|c|c|c|c|}
\hline Age (months): & $<3$ & $3-$ & $4-$ & $5-$ & 6 \\
\hline $\begin{array}{l}\text { No }(",) \text { receiving solids } \\
\text { Cumulative } ", \ldots \quad \quad \ldots\end{array}$ & $\begin{array}{c}4(11) \\
11\end{array}$ & $\begin{array}{l}9(25) \\
36\end{array}$ & $\begin{array}{c}13(36) \\
72\end{array}$ & $\begin{array}{c}8(22) \\
94\end{array}$ & $\begin{array}{l}2(6) \\
100\end{array}$ \\
\hline
\end{tabular}

*In two cases the age at which solids were introduced was not known.

TABLE IV-Different types of food eaten by children in both age groups. Figures are numbers $(\%)$ of children

\begin{tabular}{|c|c|c|c|}
\hline \multicolumn{2}{|c|}{ Types of food } & $\begin{array}{c}6 \text {-month age group } \\
(\mathrm{n}=18)\end{array}$ & $\begin{array}{l}\text { 18-month age group } \\
(\mathrm{n}=20)\end{array}$ \\
\hline $\begin{array}{l}\text { Fortified dried } \\
\text { Fortified cerea } \\
\text { Tinned baby f } \\
\text { Dehydrated ba } \\
\text { Eggs .. } \\
\text { Fish }{ }^{+} \\
\text {Rice .. } \\
\text { Dal (lentils) } \\
\text { Chapatis }\end{array}$ & 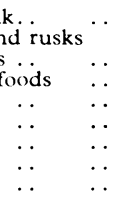 & $\begin{array}{r}12(67) \\
15(83) \\
15(83) \\
\left.\begin{array}{r}3(17) \\
13(72) \\
3(17) \\
4(22) \\
2(11) \\
0\end{array}\right\} 18(100)\end{array}$ & 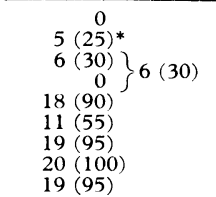 \\
\hline
\end{tabular}

*Rusks only.

†White fish only, except in two cases. months to assess the probable effectiveness of the proposed fortification of foods among these groups. The survey was carried out in Southall, Middlesex, which has a large Asian immigrant population, most of whom originate from the Punjab, $\underline{\square}$ in the north of the Indian subcontinent.

\section{Subjects and methods}

Subjects were selected by random sampling of the birth register ofo two health clinics. Initial contact with the parents was made in the company of the health visitor for their area. Of those contacted, $84 \% \overline{\bar{D}}$ agreed to allow their child to participate. The final sample consisted $\overrightarrow{\widetilde{\Phi}}$ of 38 children ( 20 aged 18 months, 18 aged 6 months) with equal numbers of each sex. Most of the children's families $(82 \%)$ came fromo the Punjab and most were Sikhs. This reflects the composition of the $\vec{P}$ Asian population in Southall. Most of the children lived in extended ${ }_{-}^{\circ}$ family groups and their fathers were generally manual workers in $\vec{\omega}$ local factories.

Each child attended a special clinic at the local hospital on one of two days in the second week of May 1977 for clinical examination, blood sampling for various estimations (subject of a separate paper), $\overrightarrow{-}$ and $x$-ray examination of the wrists of the 6-month-old infants and 9 the wrists and ankles of the 18-month-old children. One of us (NS) $\vec{\omega}$ obtained information on each child's diet in the two months after theo medical examinations by visiting each family twice. The second visit was usually two days after the first. Each interview included a quanti-o tative recall of the diet for the previous day with estimations of quantities based on household measures when necessary. Parents were $\overrightarrow{-}$ also asked about dietary history and feeding patterns; questions were 3 designed to elicit information about the child's vitamin D intake and $\frac{\varrho}{\widehat{O}}$
about Asian infant feeding practices generally.

For calculating vitamin $\mathrm{D}$ intakes the vitamin $\mathrm{D}$ contents given in $\vec{\varphi}$ the manufacturer's information on the packets of dried milks and infant cereals were used. For other infant foods vitamin $D$ content ${ }^{\circ}$ was calculated from the recipes supplied by the manufacturers with the use of the values for vitamin D given by McCance and Widdowson. ${ }^{15}$ These values were also used to calculate the vitamin $\mathrm{D}$ content of other items of the diet.

\section{Results}

None of the children in either age group were being entirely breastfed at the time of the survey. Table I shows the proportion of the total sample being breast-fed at various ages. Fortified dried milk had been given to 34 of the children at some time. The remaining four had been breast-fed for longer than average, and went straight on to "doorstep". milk after weaning. The length of time for which dried milk was usually given is shown in table II. Solids had been introduced to the children's diets at between 2 months and 1 year of age (table III). Seventeen of the children in the 18 -month age group were eating adult food including chapatis by the age of 1 year, and all of them? were on adult food at 14 months. At interview Asian adult food was $N$ found to be a major constituent of the diet of almost all the children 9 in the 18-month group. The types of food eaten by the children in the $\frac{7}{2}$ two age groups are shown in table IV. All but one of the children in the 18-month age group ate chapatis regularly. The mean daily intake $N$ of chapati flour was $18 \pm$ SD $8 \mathrm{~g}$ (range 5-31 g). According to their N parents, some of the babies in the 6 -month group were given chapatis to chew on, though they could not really be said to eat them.

The parents of 17 of the 6-month-old babies and 14 of the 18-monthold children claimed to be giving them a vitamin supplement con- $\mathbb{\Phi}$

TABLE V-Mean daily vitamin $D$ intake in both groups of children with and without vitamin $D$ supplements. Figures are numbers ( $\left.{ }^{\circ}\right)$ of children

\begin{tabular}{|c|c|c|c|c|c|c|c|c|c|c|c|c|}
\hline & & & & \multicolumn{9}{|c|}{ Daily vitamin $\mathrm{D}(\mu \mathrm{g})$} \\
\hline & & & & $<2.5$ & $2 \cdot 5-$ & $5 \cdot 0-$ & $7 \cdot 5-$ & $10 \cdot 0^{*}-$ & $12 \cdot 5-$ & $15 \cdot 0-$ & $17 \cdot 5-$ & $20 \cdot 0-22 \cdot 4$ \\
\hline \multicolumn{13}{|c|}{6 -month age group $(n=18)$} \\
\hline Without supplements & .. & . & .. & $5(28)$ & $5(28)$ & $1(6)$ & $4(22)$ & $3(16)$ & 0 & 0 & 0 & 0 \\
\hline With supplements & . & . & .. & $1(6)$ & $2(11)$ & $3(16)$ & $2(11)$ & $1(6)$ & $3(16)$ & $3(16)$ & $2(11)$ & $1 \quad(6)$ \\
\hline \multicolumn{13}{|c|}{ 18-month age group $(n=20)$} \\
\hline Without supplements & .. & .. & . & $16(80)$ & $3(15)$ & $1 \quad(5)$ & 0 & 0 & 0 & 0 & 0 & 0 \\
\hline With supplements & .. & & . & $8(40)$ & $2(10)$ & $1(5)$ & $3(15)$ & $4(20)$ & $1 \quad(5)$ & 1 (5) & 0 & 0 \\
\hline
\end{tabular}

*UK recommended daily intake $10 \mu \mathrm{g}$. 
taining vitamin $\mathrm{D}$. The mean daily vitamin $\mathrm{D}$ intakes from food calculated from the dietary recall were $5 \cdot 2 \pm$ SD $4 \cdot 1$ : $\mathrm{kg}$ in the 6 -month age group (range $0 \cdot 1-12 \cdot 1 \mathrm{~kg}$ ) and $1 \cdot 2 \pm 1 \cdot 6 \mathrm{~kg}$ in the 18 -month age group (range $0 \cdot 2-6 \cdot 2 \mathrm{~kg}$ ). Mean daily vitamin D intakes including vitamin $\mathrm{D}$ supplements which, in the dietary history, the mothers claimed to be giving were $11 \cdot 3 \pm 6 \mathrm{~kg}$ in the 6-month age group (range $0 \cdot 2-22 \mathrm{~kg}$ ) and $5 \cdot 9 \pm 5 \cdot 3 \mathrm{~kg}$ in the 18 -month age group (range $0 \cdot 2-16 \cdot 4 \mathrm{~kg})$. Fifteen $(84 \%)$ of the 6 -month-old infants and all of those aged 18 months were receiving less than the UK recommended daily intake $(10 \mathrm{~kg})^{16}$ from food sources alone (table V). With vitamin supplements included eight $(44 \%)$ of the children aged 6 months and $14(70 \%)$ of those aged 18 months were receiving less than the recommended daily intake.

In the 6-month age group the major contributors to the total vitamin $\mathrm{D}$ intakes were fortified milks (average contribution $25^{\circ} \mathrm{o}$ ), fortified cereals and rusks $\left(13^{\circ}\right)$, and vitamin supplements $\left(53^{\circ}\right)$. In the 18-month age group the main contributions were from eggs $\left(14^{\circ} \%\right)$, doorstep milk $\left(16^{\circ}{ }_{0}\right)$, and vitamin supplements $\left(47^{\circ}{ }_{0}\right)$. In the 6 -month age group only one child $\left(6^{\circ}\right)$ had both clinical and radiological evidence of rickets, but in the 18 -month age group there were four cases $(20 \%)$.

\section{Discussion}

The proportion of the sample who were breast-fed and the duration of breast-feeding were similar to those reported recently among the British population ${ }^{1 / 1}$ but contrast with the practice in India, where breast-feeding for a year or more is usual. ${ }^{19}: 0$ The large proportion of children who received fortified dried milk at some time and the use of this until many were aged 6 months or more seemed to be similar to that found in the white population. ${ }^{21}$

A major difference between Asian and British infant feeding practices is in the age at which solids are introduced. Instead of introducing solids in the first one or two months of the infant's life, as is the practice among much of the white population, ${ }^{171 \times 21}$ most of the infants in this study $\left(89^{\circ}{ }^{\prime}\right)$ did not receive solids before the age of 3 months. Nevertheless, by the age of 6 months $34\left(94^{\prime \prime}{ }^{\prime}\right)$ of the children studied had been given solid baby food, so their diet was similar to that of white infants of the same age. The large contribution of adult foods, compared with commercial baby foods, to the diets of most of the 18-month-old children was also similar to white children's diets.": The diet of Asian infants, however, is composed mainly of traditional Asian foods.

Fewer vitamin D supplements were given to the 18-month-old children, partly because they ate more often with the family and therefore were not considered to need special dietary attention. Attendance at health clinics and home visits from the health visitors, where the need for vitamin supplementation is emphasised, decline rapidly after the age of 1 year, so vitamin supplements may soon be forgotten.

The change in the diet between the ages of 6 and 18 months, from one containing reasonable amounts of vitamin $\mathrm{D}$ in the form of fortified milk and cereals to one containing very little of the vitamin, and the simultaneous decrease in the use of vitamin supplements, is reflected in the figures for daily vitamin $\mathrm{D}$ intake found in this survey. Thus the mean daily vitamin $\mathrm{D}$ intake from food sources in the 6-month age group was more than four times that of the 18-month group, and their mean daily vitamin D intake including vitamin supplements was twice that of the 18-month group. Whether vitamin supplements were actually being given, especially to some of the older children, is questionable as some people said they gave vitamins regularly but did not have any in the house.

The differences between the two groups were also reflected in finding only one child with both clinical and radiological evidence of rickets in the 6-month group compared with four in the 18-month group. Decreased use of fortified baby foods and vitamin supplements from the age of about 1 year onwards may lead to inadequate vitamin $\mathrm{D}$ intake among Asian preschool children. Thus measures to prevent vitamin $\mathrm{D}$ deficiency in Asian children above the age of 1 year seem to be needed, though the efforts of the health visitors and clinics seem to be successful in ensuring adequate vitamin D intakes in younger infants.

Educating British parents to continue vitamin supplements throughout the preschool years is difficult, and use of vitamin drops decreases after the age of 1 year. ${ }^{22}$ Among Asians, with their strong adherence to their own eating habits and the added language barrier, only limited success is likely, especially as too few health visitors are available to allow frequent domiciliary visits to children over the age of 1 year. Fortification of food therefore seems to be the best method of ensuring adequate vitamin $\mathrm{D}$ intake for these children. Both chapati flour ${ }^{12}$ and fresh milk ${ }^{11}$ may be suitable for vitamin $\mathrm{D}$ fortification, and both these items of food were consumed regularly by 19 of the 20 children in the 18-month group. If the chapati flour eaten by these children had been fortified to the level used by Pietrek et $a^{12}$ the mean daily vitamin $\mathrm{D}$ intake of the group from food would have been nearly trebled to $3.2+$ SD $2 \cdot 15 \mu \mathrm{g}$ compared with $1.2:-1.6 \mu \mathrm{g}$ without fortification. Even allowing for losses of half the vitamin $\mathrm{D}$ content during processing and cooking the mean daily intake of the group would have been $2 \cdot 2:-1.83 \mu \mathrm{g}$. Similarly, if the milk drunk by the children had been fortified to the level used in the USA ${ }^{23}$ the mean daily vitamin D intake from food sources of the 18-month group would have been improved to $5 \cdot 2: 2 \cdot 7 \mathrm{~kg}$. The effect these fortifications would have had on individual intakes is shown in table VI.

TABLE VI-Mean daily vitamin D intake in 20 18-month-old Asian children without fortification of food and mean potential intakes with fortification of milk and chapati flour. Figures are numbers $(\%)$ of children

\begin{tabular}{|c|c|c|c|c|c|}
\hline & \multicolumn{5}{|c|}{ Daily vitamin D $(\mu \mathrm{g})$} \\
\hline & $<2.5$ & $2 \cdot 5-$ & $5 \cdot 0-$ & $7 \cdot 5-$ & $10 \cdot 0^{*}-12 \cdot 4$ \\
\hline $\begin{array}{l}\text { No fortification } \\
\text { Fortification of milk } \\
\text { Fortification of chapati flour }\end{array}$ & $\begin{array}{r}16(80) \\
2(10) \\
10(50)\end{array}$ & $\begin{array}{l}3(15) \\
8(40) \\
7(35)\end{array}$ & $\begin{array}{l}1 \\
5(25) \\
2(10)\end{array}$ & $\begin{array}{l}0 \\
3(15) \\
1 \quad(5)\end{array}$ & $\begin{array}{l}0 \\
2(10) \\
0\end{array}$ \\
\hline
\end{tabular}

*UK recommended daily intake $10 \mu \mathrm{g}$.

Fortifying both these items is technically possible, but white people who dislike having their food "adulterated" might object to fortification of milk. If this problem is avoided by fortifying only some milk then the people who need it must be educated and persuaded to buy it, which might prove as difficult as encouraging the use of vitamin supplements. Because children's milk consumption tends to decrease with age ${ }^{24}$ older children, adolescents, and adults would not benefit greatly from this means of fortification, though fortified milk would help the elderly who suffer from osteomalacia. Fortifying chapati flour does not present these problems as it is eaten only by Asians, and its consumption increases with age in all groups aged over 1 year. This may therefore be the most effective way of preventing vitamin $\mathrm{D}$ deficiency among all age groups in the Asian immigrant community.

We thank Mrs D Thompson, area health education officer, Ealing, for her organisation and help; Mr M Lawrence for statistical help; the health visitors who participated in the study; and, above all, the parents and children for their conscientious co-operation.

\section{References}

${ }^{1}$ Dawson, K P, and Mondhe, M S, Practitioner, 1972, 208, 789.

2 Felton, J C, and Stone, W D, British Medical fournal, 1966, 1, 1521.

${ }^{3}$ Ford, J A, et al, British Medical fournal, 1972, 2, 677.

${ }^{4}$ Ford, J A, et al, British Medical fournal, 1973, 3, 211.

${ }^{5}$ Ford, J A, et al, Archives of Disease in Childhood, 1976, 51, 939.

${ }^{6}$ Holmes, A M, et al, Quarterly fournal of Medicine, 1973, 42, 125.

7 Benson, P F, et al, British Medical fournal, 1963, 1, 1054.

${ }^{8}$ Richards, I D G, et al, Lancet, 1968, 1, 803.

${ }^{9}$ Dent, C E, and Smith, R, Quarterly fournal of Medicine, 1969, 38, 195.

10 Goel, K M, et al, Lancet, 1976, 1, 1141. 
${ }^{11}$ Gertner, J M, and Lawrie, B, Lancet, 1977, 1, 257.

12 Pietrek, J, et al, Lancet, 1976, 1, 1145.

${ }^{13}$ Cooke, W T, et al, British Medical fournal, 1974, 2, 293.

${ }^{14}$ Hunt, S P, et al, British Medical fournal, 1976, 2, 1351.

15 McCance, R A, and Widdowson, E M, The Composition of Foods, MRC Special Report Series No 297. London, HMSO, 1960.

${ }^{16}$ Department of Health and Social Security, Reports on Public Health and Medical Subjects, No 120. London, HMSO, 1969.

${ }_{17}$ Kirk, T R, Proceedings of the Nutrition Society, 1976, 35, 79A.

${ }^{18}$ Morgan, J, et al, Proceedings of the Nutrition Society, 1976, 35, 74A.
${ }^{19}$ Bansal, R D, et al, Indian fournal of Medical Research, 1973, 61, 1869

20) Karkal, M, Indian Pediatrics, 1975, 12, 13.

21 Department of Health and Social Security, Report on Health and Social Subjects, No 9. London, HMSO, 1974.

2.2 Morgan, $\mathrm{J}$, and Mumford, $\mathrm{P}$, personal communication.

2:3 Jeans, P C, Fournal of the American Medical Association, 1950, 143, 177. ए0

24 Department of Health and Social Security, Report on Health and Social Subjects, No 10. London, HMSO, 1975.

(Accepted 22 December 1977)

\title{
High incidence of vincristine-induced neuropathy in lymphomas
}

\author{
SYLVIA M WATKINS, J P GRIFFIN
}

British Medical fournal, 1978, 1, 610-612

\section{Summary and conclusions}

The incidence of vincristine-induced neuropathy was studied in 60 unselected patients, of whom 23 had lymphoma and 37 had other malignant disease. All were treated with vincristine combined with other cytotoxic agents. Fourteen of the patients with lymphoma $(61 \%)$ developed neuropathy compared with five patients with leukaemia or non-lymphoid cancer $(14 \%)$, even though all patients received comparable doses of vincristine. The difference between the two groups in the incidence of neuropathy was highly significant. Of the patients who developed neuropathy, 17 did so within the first three months of treatment and seven in the first month.

Patients with lymphoma who are receiving vincristine should be observed carefully for symptoms and signs of neuropathy. Vincristine should be withdrawn if progressive neurotoxicity develops.

\section{Introduction}

Peripheral neuropathy is a well-known complication of vincristine treatment. Depression of the ankle-jerk reflex is almost universal, and symptoms of neurotoxicity are extremely common in patients receiving high doses. ${ }^{12}$ Nevertheless, most patients given normal doses develop areflexia and some get paraesthesiae that may be severe enough to warrant stopping treatment. ${ }^{3}$ Motor and autonomic neuropathy may also complicate vincristine treatment. ${ }^{2}$ We decided to compare the incidence of vincristine-induced neuropathy in patients with lymphoma and other malignant diseases.

\section{Patients and methods}

All patients starting treatment with vincristine in our oncology clinic between August 1974 and October 1976 were studied. During this time 60 patients with lymphoma and other malignant disease were started on courses of cytotoxic drugs including vincristine (see

Lister Hospital, Stevenage, Herts SG1 4AB

SYLVIA M WATKINS, DM, MRCP, consultant physician J P GRIFFIN, MB, PHD, clinical pharmacologist table). Twenty-three patients had lymphoma (10 Hodgkin's disease $\overline{\vec{\omega}}$ and 13 non-Hodgkin's lymphomas), 23 had metastatic breast :cancer, nine had leukaemia (five acute myeloblastic, one acute promyelocytic, one acute myelomonocytic, one blast crisis, and one acute lymphoblastic), and one each had malignant melanoma, rectal carcinoma, $\rightarrow$ bronchial carcinoma, undifferentiated sarcoma, and anaplastic $\vec{Z}$ carcinoma. Patients were followed up for a minimum of 10 months or until they died.

Definition of neuropathy-Patients receiving vincristine who com- $\stackrel{\sim}{-}$ plained spontaneously of distressing paraesthesiae with or without $\overrightarrow{0}$ numbness, wasting or muscular weakness, or severe constipation wereoo regarded as having neuropathy. Patients were deliberately not askedర about such symptoms. Areflexia unassociated with symptoms waso disregarded for the purpose of this study.

\section{Results}

INCIDENCE OF NEUROPATHY

Eighteen patients had sensory symptoms and three also had motor symptoms and signs. One patient developed ileus, presumably due to autonomic neuropathy. Ankle jerks were absent in all these 19 patients, and most of them had also lost other reflexes. Vincristine was always stopped when such symptoms developed, and in all cases the symptoms and signs then improved, usually clearing completely 3 . Areflexia alone was not regarded as sufficient reason for stopping vincristine, and indeed almost all the patients in this series had lost at $\frac{0}{3}$ least their ankle jerks.

Fourteen of the 23 patients with lymphoma $\left(61 \%_{0}\right)$ developed $\mathrm{O}$ neuropathy (table). Five of the remaining 37 patients $(14 \%)$ developed N neuropathy, of whom two had leukaemia, one breast cancer, one melanoma, and one anaplastic carcinoma. The difference between the two groups in the incidence of neuropathy was highly significant $\left(\%^{2}=14 \cdot 7 ; \mathrm{DF}=1 ; \mathrm{P}<0.0005\right)$

AGE

The mean age of patients with neuropathy was slightly but not? significantly lower than that of the patients without it $(45 \cdot 1$ and $50 \cdot 3$ years respectively; $t=1 \cdot 228 ; \mathrm{DF}=58 ; \mathrm{P} \cdot 0 \cdot 1)$. Similarly, patients $\overline{0}$ with lymphoma with and without neuropathy were of comparable mean ages $\left(47 \cdot 3\right.$ and $55 \cdot 2$ years respectively; $t=1 \cdot 139 ; \mathrm{DF}=21 ; \frac{\text { }}{\mathbb{D}}$ P. $0 \cdot 1)$, as were the patients with and without lymphoma $(50.4$ and 0 47.6 years respectively; $t=0.683 ; \mathrm{DF}=58 ; \mathrm{P}>0.2)$.

DOSE OF VINCRISTINE

The total dose of vincristine given before neuropathy developed was usually low (mean $0.14 \mathrm{mg} / \mathrm{kg}$ ). In contrast many of the patients without neuropathy had received large cumulative doses (mean $0.36 \mathrm{mg} / \mathrm{kg}$ ), in some cases for prolonged periods. Figs 1 and 2 show 